\title{
FAIR VALUE USEFULNESS IN FinANCIAL STATEMENTS
}

\section{Betakova, J.; Hrazdilova-Bockova, K. \& SkodA, M.}

Abstract: The European Commission has recently endorsed IFRS 13 on fair value measurement and is considering the endorsement of IFRS 9, which extends the use of fair value for financial instruments. The recent financial crisis has led to a vigorous debate about the pros and cons of fair-value accounting. This debate presents a major challenge for fair-value accounting going forward and standard setters' push to extend fair-value accounting into other areas. In this paper, we principally highlight four important issues as an attempt to make sense of the debate. First, much of the controversy results from confusion about what is new and different about fairvalue accounting. Second, while there are legitimate concerns about marking to market or pure fair-value accounting in times of financial crisis, it is less clear that these problems apply to fair-value accounting as stipulated by the accounting standards, be it IFRS or US GAAP. Third, historical cost accounting is unlikely to be the remedy. There are a number of concerns about historical cost accounting as well and these problems could be larger than those with fair-value accounting. Fourth, although it is difficult to fault the fair-value standards per se, implementation issues are a potential concern, especially with respect to litigation. Finally, we identify several avenues for future research.

Key words: fair value, relevance, reliability, financial statements, value relevance
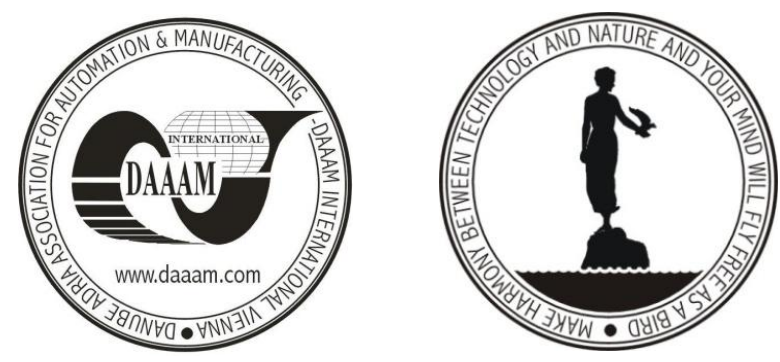

Authors' data: Ass. Prof. Dr. Betakova, J[anka]; Dr. Hrazdilova-Bockova, K[aterina]; Ass. Prof. Dr. Skoda, M[iroslav], Technology Institute in Dubnica, Dubnica nad Vahom, Sladkovicova 533/20, 01841 Dubnica nad Vahom, Slovakia, betakova@dti.sk,hrazdilova@dti.sk, skoda@dti.sk

This Publication has to be referred as: Betakova, J[anka]; Hrazdilova Bockova, K[aterina] \& Skoda, M[iroslav] (2014). Fair Value Usefulness in Financial Statements, Chapter 35 in DAAAM International Scientific Book 2014, pp.433-448, B. Katalinic (Ed.), Published by DAAAM International, ISBN 978-3-901509-98-8, ISSN 1726-9687, Vienna, Austria DOI:10.2507/daaam.scibook.2014.35 


\section{Introduction}

The recent financial crisis has turned the spotlight on fair-value accounting and led to a major policy debate involving among others the US Congress, the European Commission as well as banking and accounting regulators around the world. Critics argue that fair-value accounting, often also called mark-to-market accounting, has significantly contributed to the financial crisis and exacerbated its severity for financial institutions in the US and around the world. On the other extreme, proponents of fair-value accounting like Turner (2008) and Veron (2008) argue that it merely played the role of the proverbial messenger that is now being shot. In our view, there are problems with both positions. Fair-value accounting is neither responsible for the crisis nor is it merely a measurement system that reports asset values without having economic effects of its own.

In this paper, we attempt to make sense of the current fair-value debate and discuss whether many of the arguments in this debate hold up to further scrutiny. We come to the following four conclusions. First, much of the controversy about fairvalue accounting results from confusion about what is new and different about fairvalue accounting as well as different views about the purpose of fair-value accounting. In our view, the debate about fair-value accounting takes us back to several old accounting issues, like the trade-off between relevance and reliability, which have been debated for decades. Except in rare circumstances, standard setters will always face these issues and tradeoffs; fair-value accounting is just another example. This insight is helpful to better understand some of the arguments brought forward in the debate.

Second, there are legitimate concerns about marking asset values to market prices in times of financial crisis once we recognize that there are ties to contracts and regulation or that managers and investors may care about market reactions over the short term. However, it is not obvious that these problems are best addressed with changes to the accounting system. These problems could also (and perhaps more appropriately) be addressed by adjusting contracts and regulation. Moreover, the concern about the downward spiral is most pronounced for fair-value accounting in its pure form but it does not apply in the same way to fair-value accounting as stipulated by US GAAP or IFRS. Both standards allow for deviations from market prices under certain circumstances (e.g., prices from fire sales). Thus, it is not clear that the standards themselves are the source of the problem.

However, as our third conclusion highlights, there could be implementation problems in practice. It is important to recognize that accounting rules interact with other elements of the institutional framework, which could give rise to unintended consequences. For instance, we point out that managers' concerns about litigation could make a deviation from market prices less likely even when it would be appropriate. Concerns about SEC enforcement could have similar effects. At the same time, it is important to recognize that giving management more flexibility to deal with potential problems of fair-value accounting (e.g., in times of crisis) also opens the door for manipulation. For instance, managers could use deviations from allegedly depressed market values to avoid losses and impairments. Judging from 
evidence in other areas in accounting (e.g., loans and goodwill) as well as the US savings and loans crisis, this concern should not be underestimated. Thus, standard setters and enforcement agencies face a delicate trade-off (e.g., between contagion effects and timely impairment).

Fourth, we emphasize that a return to historical cost accounting is unlikely to be a remedy to the problems with fair-value accounting. Historical cost has a set of problems as well and it is possible that for certain assets they are as severe, or even worse, than the problems with fair value. For instance, historical cost accounting likely provides incentives to engage in so-called "gains trading" or to securitize and sell assets. Moreover, lack of transparency under historical cost accounting could make matters worse during crises.

We conclude our article with several suggestions for future research. Based on extant empirical evidence, it is difficult to evaluate the role of fair value in the current crisis. In particular, we need more work on the question of whether market prices significantly deviated from fundamental values during this crisis and more evidence that fair-value accounting did have an effect above and beyond the procyclicality of asset values and bank lending.

The paper proceeds as follows. First, we provide a quick overview over fair value as an exit price and some of the key arguments for and against fair value accounting. Second, we compare fair-value and historical cost accounting and shortly discuss fundamental tradeoffs involved when choosing one or the other. Third, we discuss the concern that fair value accounting contributes to contagion and procyclicality as well as its usefulness in financial statements. Finally there is a debate about the pros and cons of dual measurement and reporting system.

\section{Fair value as an exit price}

Recently, the European Commission has endorsed IFRS 13, Fair Value Measurement, which sets out a single framework for measuring fair value and provides comprehensive guidance on how to measure it. IFRS 13 is the result of a joint project conducted by the IASB together with FASB, which led to the same definition of fair value as well as an alignment of measurement and disclosure requirements to FAS 157. Both FAS 157 and IFRS 13 define fair value as the price that would be received to sell an asset in an orderly transaction between market participants at the measurement date. This definition of fair value reflects an exit price option, which is the market price from the perspective of a market participant who holds the asset. Moreover, fair value must be a market-based, not an entityspecific measurement, and the firm's intention to hold an asset is completely irrelevant. For instance, the application of a blockage factor to a large position of identical financial assets is prohibited given that a decision to sell at a less advantageous price because an entire holding, rather than each instrument individually, is sold represents a factor which is specific to the firm. If observable market transactions or market information are not directly observable, the objective of fair value measurement still remains the same, that is to estimate an exit price for the asset, and the firm shall use valuation techniques. Valuation techniques shall be 
consistent with the market approach, income approach or cost approach. The market approach uses prices and other relevant information generated by market transactions involving identical or comparable assets. The income approach uses valuation techniques to convert future amounts (e.g. cash flows or income and expenses) to a single present amount. Such valuation techniques include present value techniques, option pricing models - such as the Black-Scholes-Merton formula and the binomial model- and the multi-period excess earnings method. The cost approach, instead, reflects the current replacement cost, that is the amount that would currently be required to replace the service capacity of an asset. Inputs to valuation techniques are categorized into a fair value hierarchy which gives the highest priority to quoted prices (unadjusted) in active markets for identical assets (Level 1 inputs) and the lowest priority to unobservable inputs (Level 3 inputs). Level 1 inputs are quoted prices (unadjusted) in active markets for identical assets that the firm can access at the measurement date. With Level 1 puts information asymmetry between management and investors is very low. Hence, quoted prices in active markets must be used whenever available. Level 2 inputs are inputs, other than quoted prices, that are observable - either directly or indirectly - for the asset. Level 2 inputs include quoted prices for similar assets in active markets; quoted prices for identical or similar assets in markets that are not active; inputs other than quoted prices that are observable for the asset, such as interest rates and yield curves observable at commonly quoted intervals, volatilities, prepayment speeds, loss severities, credit risks, default rates; inputs that are derived principally from or corroborated by observable market data by correlation or other means. Level 2 inputs are expected to have great reliability as they are corroborated by observable market data. Adjustments to Level 2 inputs that are significant to the entire measurement result in a fair value measurement categorized within Level 3. Level 3 inputs are unobservable inputs for an asset fair value measurement. Unobservable inputs are inputs for which market data are not available and, therefore, need to be developed on the basis of the best information available about the assumptions that market participants would use when pricing the asset. Level 3 inputs are subject to the highest degree of information asymmetry between preparers and users. As mentioned, fair value must be an exit value, that is, a market price from the perspective of market participants at the measurement date.

The accounting system which uses market selling prices to measure a firm's financial position and financial performance is called exit price accounting. Exit price accounting is associated mainly with the works of Robert Sterling (1970), and Kenneth Mac Neal (1970). Sterling bases his proposal for exit price accounting on a notion of adaptive behaviour of a firm. In fact, he sees the firm as an adaptive entity engaged in buying and selling goods and services. The firm is governed by the decisions of its managers who represent the owners' objectives and the owners consider the firm to be an instrument by which they hope to increase their real financial wealth. The concept of adaptive behaviour sees the firm as always being ready to dispose of an asset if this action is in its best interest. For instance, the firm keeps a non-current asset only if the present value of the future net cash flow from the use of the asset is greater than the present value of the expected net cash flow 
from an alternative investment of the exit value of the asset. At all times, therefore, the firm must consider whether an alternative opportunity for greater returns exists for its assets if they were sold and the proceeds invested. This is an opportunity cost concept, which uses the exit price as a measurement base. Adaptive behaviour therefore calls for knowledge of the cash and current cash equivalents of the firm's net assets. The selling price reveals the firm's ability to go into the market for the purpose of adapting itself to present conditions. Sterling also considers the question of being additive to be a key factor in support of exit price accounting. The main products of accounting are the balance sheet and income statement. If different measurement scales are used for the different items, they cannot logically be added together, and no practical or commercial meaning can be deduced from the aggregate. According to Sterling, the use of either historical cost for some assets, of replacement cost for others, or present value for other ones or cash do not lead to a meaningful balance sheet. Nor can a jumble of historical costs based on different dates lead to a meaningful calculation of net assets.

Mac Neal (1970) claims that the historical cost accounting is based on conditions which have largely ceased to exist. Towards the end of the nineteenth century firms grew larger and many became companies with a multitude of shareholders and hired managers. In the twentieth century, firms were generally owned by numerous shareholders who relied on financial statements and the media for their information about the company they owned. As a result, accounting has become more and more important for shareholders. Mac Neal contends that conventional accounting principles based on historical cost provides potentially false and misleading financial statements that do not serve decision-oriented shareholders. Shareholders cannot learn the current values of the company assets from a balance sheet based on historical cost accounting and they are also at a disadvantage compared with insiders who have this information. The ideal solution is therefore to report all profits and losses and values as determined in competitive markets. Sterling (1970) uses a simple model - a wheat trader in a perfect market with a stable price level - to show that exit price is better than all others accounting measurements. For the wheat trader, three decision problems are: the decision to enter and stay in the market, the decision to hold either cash or wheat and the evaluation of past decisions. The information relevant to the above decisions are the expected future price of wheat, the expected future price of alternatives, the present selling price of wheat, the present buying price of alternatives, the price at the last evaluation, the quantity of wheat and money at the last evaluation and the present quantities. The present selling price of wheat is the only item of information that is relevant to all decisions. The others are relevant to one or more, but not all, decisions. Even when the assumption of perfect competition and stable prices is relaxed, Sterling contends that the exit price is still superior.

In an effort to harmonize accounting practices, the European Union has started adopting directives as early as 1970s. In 2000 the EU made a crucial step to that end by proposing to adopt accounting standards called the International Financial Reporting Standards (IFRS) as developed by a private organization based in London UK called the International Accounting Standards Board (IASB). 
The European Parliament adopted these new accounting standards in 2002 in a new legislative that came into effect 3 years later and thus led some European companies to introduce themselves to a new accounting principle known as fair value'. The logic of this change is rooted in the deficiencies the Europeans perceived in their contemporary accounting system known as 'historical cost'. Using this method, their financial statements indicated a depreciated value of their past acquisitions. This value was seen by critics as misleading, not indicative of a real wealth of a firm. The aim and the promise of a fair value accounting are thus seen in its ability to project this wealth reliably.

The fair value accounting has not become the main method of accounting in Europe and it is questionable whether it ever will. In the IFRS standards, fair value and historical cost remain methods of choice for firms and financial institutions. The IASB continues to develop the concept of fair value accounting, trying to limit the vagueness of this approach and clarify its utility and applicability. Nevertheless, fair value continues to have many critics. The reasons why this is the case will be elaborated in the next section of this paper that deals with disadvantages.

\section{Advantages and disadvantages of fair value in financial statements}

It is a normative truth in the world of accounting that for a financial statement or any accounting data to be useful, the two most important characteristics have to be relevance and reliability. Taking these two features as a starting point, the following section will explore in the detail how well fair value accounting stands vis-à-vis these challenges.

The pros and cons will be evaluated not only from the point of a firm - an internal view but also from an external view, from a viewpoint of a potential investor or a financial institution.

\section{Timely/relevant information}

Since fair value accounting utilizes information specific for the time and current market conditions, it attempts to provide the most relevant estimates possible. It has a great informative value for a firm itself and encourages prompt corrective actions.

\section{More information in the financial statements than historical cost}

Fair value accounting enhances the informative power of a financial statement as opposed to the other accounting method - the historical cost. Fair value accounting requires a firm to disclose extensive information about the methodology used, the assumption made, risk exposure, related sensitivities and other issues that result in a thorough financial statement. Inclusion of more information is possible whenever there are:

- observable market prices that managers cannot materially influence due to less than perfect market liquidity;

- independently observable, accurate estimates of liquid market prices. 
Thusly produced financial statements therefore increase transparency of a firm, which is particularly useful to potential investors, contractors and lenders as they have a better perception of the stability of a given firm and insight into its wealth.

\section{Reliable Information}

For a financial data to be reliable they ought to be verifiable and neutral. Since fair value is inferred from the market price of a given asset, this value can be checked in hindsight from available information about current and past market prices. Since it is necessary to include the methodology and disclose the information about possible deviations from a quoted price in the financial statement, this information can also be verified. Neutrality is meant to represent a value that is best explained as an objective value and therefore devoid of any factors that would cause a rise or fall in such a value, atypical of general market conditions. For example this is a value that does not include specific information related only to the owner of a given asset. An owner of a firm is likely to seek complementary properties or assets so that a value of a single asset/property is that much higher for the firm as it not only represents its own individual value but also an additional value, as a part of a distinct and functional whole. A neutral value does not consider this asset-specific information and only makes an estimate of its value based on general publicly-known information and thus makes this estimate reliable.

\section{Pricing deviation}

One of the most often quoted disadvantages of fair value accounting is the vagueness of the measurement procedure of assets for financial statements which creates loopholes for pricing deviations. There are several ways that this measurement could produce differing prices and thus result in a deviation from a desired fair value.

\section{Misleading Information}

It is possible that sometimes the observed value of an asset in the market is not indicative of the asset's fundamental value. Market might be inefficient and not reflect in its estimates all publicly available information. There are also other factors that could cause that this market estimate to be deviated such as investor irrationality, behavioural bias or problems with arbitrage among others.

Ball (2006) also points out that market liquidity is a potentially important issue because spreads can be large enough to cause substantial uncertainty about fair value and hence introduce large overall value deviations ('noise') in the financial statements.

\section{Manipulation}

Manipulation of the price by the firms themselves also presents a risk in obtaining a fair value estimates because in illiquid markets, trading by firms can have an effect on both traded and quoted prices. 
Absence of a market price

If a market price for a given asset is not available in the active market, fair value estimate that is supposed to provide the most reliable information is more difficult to obtain. In this case, the usual procedure is to use "mark to model" accounting. This requires creation of a more extended estimate which runs the risk of creating a deviation of price for a given asset from its price if it was to be found in the market.

Furthermore if this 'mark to model' method is used to simulate a market price for a given asset, it provides an opportunity for the firm to manipulate this estimate, as it is the managers of the firm that can decide on what kind of a model or a parameter would be used.

\section{Limited reliability}

It is arguable that the information available in the financial statements provided by the fair value accounting method is relevant and reliable only for a limited period. As the information included in the statements is time-specific for given market conditions, a change in the market environment could cause a major difference in the actual financial situation of a firm. For an inexperienced professional in the accounting realm, a changing market situation would thus cause confusion as to what is the actual wealth of a firm. To get reliable information this individual would have to request a new financial statement. This could become a costly business if this request is made often. On the other hand, it is likely that an experienced businessman is able to infer the changing value of a business without the need to request a new financial statement, given he understands the procedures involved in utilizing fair value method.

\section{Volatility}

The problem of volatility is closely related to the previous issue of limited reliability. If the fair value of an asset follows the development of a market environment, this means that the value of an asset changes with the market. If the market with regards to the nature of a given asset booms, the price of a given asset goes up; if it busts, the price goes down too. A volatility of the market, which is an existing possibility, therefore creates a superfluous risk and could adversely affect the investment capacity of a firm. According to the research conducted by the European Central Bank's experts 'for assets and liabilities held to maturity, the volatility reflected in the financial statements is artificial and can be ultimately misleading, as any deviations from cost will be gradually compensated for during the life of the financial instrument, "pulling the value to par" at maturity".

\section{Contribution to the procyclicality of the Financial System}

Following the recent financial crisis, there has been a debate about the potential contribution of fair value accounting. Many believe that it exacerbated the effects of the crisis, through increasing the inherent procyclicality of the financial system. (Procyclicality refers to the ability to exaggerate financial or economic fluctuations.) Fair value accounting and its dependency on the development of the market situation could cause that a market that experiences a slump is closely followed by a deterioration of a firm's financial situation that in turn causes the market to panic, bringing it closer to an outbreak of a crisis. Since financial institutions are closely 
related to firms and the business cycle in general, if fair values indicate a fall, losses will also be reflected on the banks' capital. This kind of weakening of bank balance sheets has been a disconcerting event for a future development of some markets, and the state of the whole financial system. In practical terms, this potential of fair value accounting to contribute to the procyclicality of the financial system would cause that increases in bank profits would be exaggerated during upturns in the market and would encourage an 'overextension of credit', that would then 'create the conditions for a deeper and more long-lasting downturn. This would then also be exacerbated by the effect that downward adjustments in asset valuations would have on bank profits and capital, which would further restrain their lending. Moreover, another potential result would be to limit credit availability to counterparties whose credit status is more volatile, e.g. small and medium-sized enterprises (SME). Given the importance of SMEs in Europe this may have a detrimental effect on future economic developments.

\section{Fair value usefulness in financial statements}

When assessing the quality of fair value information, a natural question to ask is whether this information is useful to investors. In fact, the main objective of financial reporting is to provide information that is useful to investors, creditors and others in making investment, credit and similar resource allocation decisions. Although financial reporting users include a large numbers of subjects, both the FASB and IASB focus on the needs of participants in capital markets. This is because investors are considered the ones who are most in need of information from financial reports as they cannot usually request information directly from the firm. Moreover, as they provide risk capital to firms, the provisions of financial statements that meet their needs also meet most of the needs of other users. As a result, investors' needs are considered as highly representative of the needs of a wide range of users. For this reason, empirical research has long been focusing on the relation between fair value accounting and share prices or returns. Equity values reflect an accounting amount only if the information is relevant to investors in valuing a firm and is measured reliably enough to be reflected in share prices (Barth et al., 2001). Most of the research on fair value accounting has focused on the US as fair value accounting has long been used there. Furthermore, empirical studies have mainly focused on banks, which are largely comprised of financial assets and liabilities measured at fair value. Although this literature provides useful insight into the contribution of fair value to financial reporting quality, it must however be taken with some caution. In fact, many studies are prior to FAS 157 and IFRS 13, when fair value was not clearly defined as exit value, nor was the procedure for absence of active markets clearly laid-out. 4.1. Fair value relevance for financial instruments. As mentioned, much of the research on fair value accounting has focused on the bank sector providing mixed results. Barth (1994), for instance, examines a sample of US banks with data from 1971-1990 and finds that investment securities' fair values are incrementally associated with bank share prices after controlling for their book values. However, when examined in an annual return context, results provide instead mixed evidence. One leading candidate 
for ambiguous finding is that the securities' gains and losses estimates contain too much measurement error relative to the true underlying changes in their market values. Using essentially the same database, Barth et al. (1995) confirms the Barth (1994) findings and lends support to the measurement error explanation. In fact, fair value-based measures of net income are found to be more volatile than historical based measures, but incremental volatility is not reflected in bank share prices. Petroni and Wahlen (1995) find that fair values of equities and Treasury securities are value-relevant, whereas fair values of municipal and corporate bonds are not, thus suggesting that fair values of securities actively traded in the market are considered as more reliable. Nelson (1996) documents that fair value of bank loans; deposits and long-term debt are not value-relevant.

In contrast, Barth et al. (1996) find that fair values of loans are value-relevant, whereas Catty (2009) find the value relevance of loans only in limited settings. Finally, Venkatachalan (1996) examines the value relevance of derivative fair values and finds that such fair values are positively associated with equity market value. Empirical research therefore shows that fair value relevance varies according to the source of information. This issue has been further investigated after the FAS 157 issuance as valuation inputs have been categorized into a three level fair value hierarchy. Estimating fair value for assets and liabilities is in fact relatively easy if they are actively traded in liquid markets, whereas it becomes more complicated if active markets do not exist. When there is not a directly observable exit price, valuation techniques must be used to measure fair value. Valuation techniques use Level 2 or Level 3 inputs of the IFRS 13 and FAS 157 fair value hierarchy. Using a sample of large financial institutions, Krabec (2009) documents a significant positive association between stock prices and fair values of net assets measured using all the inputs of the fair value hierarchy. However, the coefficients on mark-to-model estimates are consistently lower than those on the mark-to-market fair values (Level 1 ), even though the difference is significant only for Level 3 net assets. This study suggests that investors are aware of estimation errors and, therefore, value the three levels of the fair value hierarchy differently. Marik (2011) also observe significant variation in the pricing of different levels of fair value assets, with the pricing being less for mark-to-model assets, i.e. assets with lower liquidity and greater information risk, than for mark-to-market assets. They also find that the pricing of mark-to-model assets declined over the course of 2008, consistent with increasing market concerns about illiquidity and information risk associated with these assets. Using a sample of quarterly report by banking firms, Song et al. (2010) find evidence that fair value measurements of Level 1, Level 2, and Level 3 inputs are all value-relevant, consistent with prior research. However, Level 3 assets are valued less than Level 1 and Level 2 assets. In addition, coefficients on Level 3 fair values are less than 1, which suggests that investors perceive reliability concerns for Level 3 assets. As for Krabec (2009), the lower valuation of Level 3 assets is consistent with investors decreasing the weight they place on less reliable fair value measurements. Some studies have focused directly on the predictive capability of mark-to-model valuation techniques. Kim and Ritter (1999), for instance, examine the predictive ability of market multiples based on historical numbers and find that they do a relatively poor 
job without further adjustments for differences in growth and profitability. Priceearnings multiples using forecasted earnings result instead in much more accurate valuation. Muller and Riedl (2002) find that transaction and market multiples tend to estimate exit values. Transaction multiples are in fact cases of 'revealed preferences', i.e. they refer only to successful transactions and incorporate synergy expectations as well as other positive factors which increase transaction prices, while market multiples tend to elide the idiosyncratic component of risk. Finally, Fiechter and Novotny-Farkas (2011) provide evidence that value relevance of fair value estimates also varies cross section ally and across time. Using an international sample of banks from IFRS adopting countries, they demonstrate that fair values are generally value relevant, although valuation coefficients vary with institutional and firm-specific factors. In fact, optionally fair valued assets appear to experience a discount in countries with low regulatory quality. Furthermore, they show that significant exposures to subprime investments result in substantially lower value relevance for financial assets at fair value. They also find that the value relevance of fair value assets has decreased as the financial crisis worsened. Much of the empirical research on non-financial assets has also focused on the United States as well as on Australia and the United Kingdom as these countries have long permitted upward asset revaluation for such assets. Most studies, including Easton et al. (1993), Barth and Clinch (1996), Barth and Clinch (1998) and Muller and Riedl (2002), examine revaluations of tangible fixed assets, which fall into Level 3 category of the fair value hierarchy and are therefore subject to a greater amount of management discretion.

Using a sample of Australian firms with data from 1984-1990, Easton et al. (1993) estimate annual return regressions and find that asset revaluations of tangible long-lived assets have incremental explanatory power relative to earnings and changes in earnings. Barth and Clinch (1996) also use a sample of Australian firms but from a later period, 1991-1995, and estimate annual stock price regressions to determine if financial, tangible, and intangible asset revaluations have incremental explanatory power relative to operating earnings and equity book value less the book value of re-valued assets. Barth and Clinch (1996) find re-valued investments are incrementally priced. Contrary to the view that intangible asset revaluations are likely to be noisy and uninformative, their study finds a positive association between such revaluations and share prices. With the exception of mining firms, they instead fail to find a significantly positive association between and equipment revaluations. By focusing on investment property firms, Muller and Riedl (2002) find evidence that the market finds asset revaluations estimates made by external appraisers more informative than those made by internal appraisers, thus suggesting external appraisals to be more reliable. This result is in line with Cotter and Richardson (2002), who also found that external appraisals are more reliable than those made by directors for a sample of Australian firms from the 1981-1994 period. Finally, Aboody et al. (1999) examine the performance prediction and pricing implications of fixed asset revaluations for a sample of UK firms from the 1983-1995 period. Findings show that upward revaluations are significantly positively related to changes in future performance, measured by operating income and cash from operations. Current year revaluations are also significantly positively related to annual stock 
returns, and current year asset revaluation balances are significantly positively related to annual stock prices. However, the study also finds that relations between revaluations and future performance and prices are weaker for higher debt-to-equity ratio firms, thus suggesting that managerial manipulation affects the usefulness of asset revaluations made by managers of firms facing the pressure of financial distress.

\section{Adual measurement and reporting system}

Overall, empirical findings raise some doubts on fair value estimates' usefulness to investors. For this reason, opponents to fair value often call for a return to historical cost accounting. Fair value has the great advantage that it provides a measure of what a certain investment is supposed to bring. On the other side, historical cost is useful to investors for two main reasons: it is based on actual, not merely possible transactions, and it provides investors with a measure of the resources which have been sacrificed to obtain that investment. Actually, the debate about accounting measurement has always been framed in terms of making a choice between fair value and historical cost accounting, with the former serving a decision usefulness objective and the latter a stewardship one. Over time, standard setters have become more and more oriented towards the decision usefulness of financial information, thus abandoning the historical cost accounting in favour of fair value accounting. This paper claims that such a debate should be reframed and no longer considered in terms of the choice between fair value and historical cost. In fact, choosing between historical cost and fair value accounting implies sacrificing one these two objectives. A dual measurement and reporting system could be the solution to such a controversy. Historical cost and fair value provide two different kinds of information, which are both useful to investors. At the time of acquisition, fair value and historical cost are in most cases equal, but they do normally diverge in subsequent periods. Following acquisition, historical cost accounting and fair value accounting provide different information and serve different purposes. Fair value is needed for ranking and sorting out competing investment alternatives.

Reporting how much the entity invested to acquire an asset is not, by itself, fully informative as it does not offer any insights about the quality of that investment. In order to assess that quality, users need to know what that investment is expected to bring in the future. With some cautions on fair value estimates' reliability, fair value accounting provides investors with useful information about expected benefits from a certain investment.

However, fair value alone cannot help investors to properly evaluate stewardship, that is, the careful and responsible management of funds. In fact, financial statement users would not know how much resources the management has paid to obtain that fair value. Historical cost is therefore useful for stewardship and control decisions as it tracks the amount paid for resources. A given resources owned by two different entities will have the same fair value at any given time, but fair value does not inform investors that one entity have probably paid a different price for the same asset. In order to effectively evaluate stewardship, knowledge of fair value is not enough. Users also need to know the historical cost of the investment. 
Indeed, the best understood concept of profit is the excess of selling price over historical cost. Decisions on whether to continue a product line or division or factory depend to a large extent on whether there is a favourable spread between revenue and cost. As a result, this paper claims that historical cost and fair value should not be considered as competitors and both of them should be provided. An attempt to choose either one would deprive financial statement users of access to complete and useful information for decision-making. For this reason, a dual measurement and reporting model should be a good solution. A dual measurement and reporting model could be more effective for assessing the success of an investment. Comparing expected events (i.e. fair values) with past events (i.e. historical costs) would improve the ability of financial statement users to evaluate both past performance, thus fulfilling a stewardship objective, and to predict future performance, thus fulfilling a decision usefulness objective.

\section{Conclusion}

This paper highlights that historical cost and fair value accounting must not be considered as competitors, as they serve different purposes. Historical cost provides investors with the cost of the investment, while fair value gives a measure of what the management expect to get in return from a certain investment. Knowledge of fair value is important, although it is not enough. Users also need to know the cost of the investment. In fact, knowing how much resources have been sacrificed to obtain that fair value, they could effectively evaluate stewardship. This paper therefore concludes that both historical cost and fair value should be provided as only together they can deliver complete and useful information to investors. As a consequence, the adoption of a dual measurement and reporting system should be considered and discussed at a standard setting level.

According to the advantages and disadvantages of the concept of fair value in accounting, it is quite obvious and clear that this concept is far from being perfect. It is very difficult to determine whether its contribution to the improvement of accounting is really beneficial. On the one hand there are many reasons why the users of this method are better off, but on the other hand there are also several reasons why they are worse off. In fact, many of relevant sources express their mixed views about the extent to which IFRS are becoming imbued with the current IASB/FASB fascination with fair value accounting. Although the fair-value discussion seems to be far from over now, the current crisis provided an interesting setting to further explore these issues, understand them better and hopefully urge responsible institutions to fix the imperfections within the system to make it work correctly and more effectively.

The preceding sections illustrate that the debate about fair-value accounting is full of arguments that do not hold up to further scrutiny and need more economic analysis. Moreover, it is important to recognize that standard setters face tradeoffs, and in this regard fair-value accounting is no exception. One example is the trade-off between relevance and reliability, which is at the heart of the debate of when to deviate from market prices in determining fair values. Another example is that fairvalue accounting recognizes losses early thereby forcing banks to take appropriate 
measures early and making it more difficult to hide potential problems that only grow larger and would make crises more severe. But this benefit gives rise to another set of tradeoffs. First, fair-value accounting introduces volatility in the financial statement in "normal times" (when prompt action is not needed). Second, full fair-value accounting can give rise to contagion effects in times of crisis, which need to be addressed - be it in the accounting system or with prudential regulation. In our view, it may be better to design prudential regulation that accepts fair-value accounting as a starting point but sets explicit counter-cyclical capital requirements than to implicitly address the issue of financial stability in the accounting system by using historical costs. It is an illusion to believe that ignoring market prices or current information provides a foundation for a more solid banking system. But we admit that the tradeoff between transparency and financial stability as well as the interactions between accounting and prudential regulation needs further analysis. In addition, we have several other suggestions for future research.

First and foremost, we need to make more progress on the question of whether fair value did in fact contribute to the financial crisis through contagion effects. At present, there is little research that would answer or even directly speak to this question. The SEC study mandated by Economic Stabilization Act of 2008 argues that fair-value accounting did not cause bank failures because the fraction of assets reported at fair value was small in most cases, and in those cases where the fraction of fair-value assets was larger, the share price reflected even higher losses than were reported by the bank. While this argument and the accompanying evidence point to real losses as the source of bank failures, they do not provide convincing evidence that there was no contagion. The failure of some banks could have increased market illiquidity, which in turn may have spilled over to other banks via fair value. Moreover, it is tricky to use banks' share prices as evidence that fair-value accounting did not have any negative effects for banks with a large fraction of fairvalue assets since the share price may already reflect the negative real effects of fair value (e.g., asset fire sales in illiquid market).

A first step towards making progress on the role of fair value accounting in the crisis is to be more explicit about the mechanism of contagion. A simple reference to models that show contagion effects in pure mark-to-market settings is not sufficient to explain the role of fair value in practice. However, the main challenge in finding evidence on contagion effects related to or caused by fair-value accounting likely lies in isolating accounting effects and separating them from contagion effects due to correlated (real) risks. This is not a trivial exercise. One important step would be to show that prices were indeed distorted and deviated substantially from fundamental values, which is not an easy task either. Similarly, we do not have evidence that banks' write-downs on securities were indeed excessive relative to their fundamentals. Interestingly, banks have also not put forward such evidence even though they should have strong incentives to do. As we noted earlier, banks are not constrained by the accounting standards from providing additional disclosures about the fundamental values of their assets. But it is possible that litigation risks or concerns about investor rationality inhibit such disclosures. 
This brings us to a second avenue for future research. Our analysis suggests that implementation problems and, in particular, litigation risks could have played a role for the performance of fair value standards and banks' reporting practices in the crisis. It would be interesting for future research to explore this possibility and to study the interactions between fair-value accounting and other important elements of the institutional framework (e.g., litigation system, SEC enforcement). Understanding these interactions and the role of fair value in the current crisis is also crucial for the decision of whether or not to expand the use of fair value to other assets and other areas of accounting.

Third, although most of the debate seems to be focused on the role of fair value in the crisis, it seems equally important to ask and study to what extent historical cost accounting (e.g., for loans) may have played a role. We already noted that historical cost accounting may have fed into the securitization boom. Moreover, there is evidence suggesting that banks' loan losses exceeded fair-value losses on securities.

Finally, it is important to recognize that accounting rules and changes in them are shaped by political processes (like any other regulation). The role of the political forces further complicates the analysis. For instance, it is possible that changing the accounting rules in a crisis as a result of political pressures leads to worse outcomes than sticking to a particular regime. In this regard, the intense lobbying and political interference with the standard setting process during the current crisis provide a fertile ground for further study. In sum, the fair-value debate is far from over and much remains to be done.

\section{References}

Aboody, D.; Barth, M.E. \& Kasznik, R. (1999). Revaluations of fixed assets and future firm performance. Journal of Accounting and Economics, Vol. 26, No. 1, (Feb 1999), pp. 149-178, ISSN 0165-4101

Ball, R. (2006). International Financial Reporting Standards (IFRS): Pros and Cons for Investors, Accounting \& Business Research, Vol. 36 (Special issue), (Apr 2006), pp. 5-27, ISSN 0001-4788

Barth, M.E. (1994). Fair value accounting: evidence from investment securities and the market valuation of banks. The Accounting Review, Vol. 69, No. 1, (Jan 1994), pp. 1-25, ISSN 0001-4826

Barth, M. E.; Landsman W.R. \& Wahlen, J. (1995). Fair value accounting: effects on banks' earnings volatility, regulatory capital, and value of contractual cash flows. Journal of Banking and Finance, Vol. 19, No. 3-4, (May 1995), pp. 577-605, ISSN 0378-4266

Barth, M.E.; Clinch G. (1996). International differences in accounting standards: evidence from UK, Australian, and Canadian firms. Contemporary Accounting Research, Vol. 13, No. 1, (Jan 1996), pp. 135-170, ISSN 1911-3846

Barth, M.E.; Clinch G. (1996). Re-valued financial, tangible, and intangible assets: associations with share prices and non market-based value estimates. Journal of Accounting Research, Vol. 36 (Special issue), (Apr. 1996), pp. 199-233, ISSN 1475$679 \mathrm{X}$ 
Barth, M. E.; Beaver, W.H. \& Landsman, W.R. (2001). The relevance of the value relevance literature for accounting standard-setting: Another view. Journal of Accounting and Economics, Vol. 31, No. 1-3, (June 2001), pp. 77-104, ISSN 01654101

Catty, J. (2009). Guide to fair value under IFRS. John Wiley \& Sons, ISBN 978-0470-47708-3, New Jersey, USA

Cotter, J.; Richardson, S. (2002). Reliability of asset revaluations: the impact of appraiser independence. Review of Accounting Studies, Vol. 7, No. 4, (Dec 2002), pp. 435-457, ISSN 1380-6653

Easton, P.D.; Eddey, P.H. \& Harris, T.S. (1993). An investigation of revaluations of tangible long-lived asset. Journal of Accounting Research, 31, Vol. 38, No.1, (Feb 1993), pp. 32-44, ISSN 1475-679X

Fiechter P.; Novotny-Farkas, Z. (2011). Pricing of fair values during the financial crisis: international evidence. Proceedings of the 8-th European Conference on Management, Leadership and Governance, Politis, J. (Ed.), pp. 27-32, ISBN 978-1908272-75-1, Cyprus, Nov 2011, Neapolis University, Pafos

Kim, M.; Ritter, J.R. (1999). Valuing IPOs. Journal of Financial Economics, Vol. 53, No. 3, (Nov 1999), pp. 409-437, ISSN 0304-405X

Krabec, T. (2009). Business valuation standards and values. Grada Publishing, ISBN 978-80-247-2865-0, Praha, Czech Republic

Mac Neal, K. (1970). Truth in Accounting. Scholars Book, ISBN 978-0914348047, Kansas, USA

Marik, M. (2011). Valuation methods are the measurement process - the basic methods and procedures. Ekopress, ISBN 978-80-8692980-4, Praha, Czech Republic. Muller, K.A.; Riedl, E.J. (2002). External monitoring of property appraisal estimates and information asymmetry. Journal of Accounting Research, Vol. 40, No.3, (Sep 2002), pp. 865-881, ISSN 1475-679X

Petroni, K.; Wahlen, J.M. (1995). Fair values of equity and debt securities and share prices of property-liability insurer. The Journal of Risk and Insurance, Vol. 62, No. 4, (Dec 1995), pp. 719-737, ISSN 1539-6975

Song, C.J.; Thomas, W.B. \& H. Yi (2010). Value Relevance of FAS No. 157 Fair Value Hierarchy Information and the Impact of Corporate Governance Mechanisms. The Accounting Review, Vol. 85, No. 4, (Dec 2010), pp.1375-1410 ISSN 0001-4826

Sterling, R. (1970). Theory of the measurement of enterprise income. University Press of Kansas, ISBN 978-80-700600-46-5, Kansas, USA

Turner, L. (2008). Banks want to shoot the messenger over fair value rules. Financial Times, (Oct 2008), p.17

Venkatachalam, M. (1996). Value relevance of banks' derivatives disclosures. Journal of Accounting and Economics, Vol. 22, No. 1-3, (Aug 1996), pp. 327-355, ISSN 0165-4101

Veron, N. (2008). Fair value accounting is the wrong scapegoat for this crisis. European Accounting Review, Vol. 5, No. 2, (May 2008), pp. 63-69, ISSN 14684497 